\title{
The Grounding System in Feeder Tomat PT. PLN (Persero) ULP Mariana
}

\author{
Bambang Guntoro ${ }^{1, *}$ Siswandi $^{1}$ Zainuddin Idris $^{1}$ M. Yunus ${ }^{1}$
}

\author{
${ }^{1}$ Department Polytechnic of Sriwijaya \\ ${ }^{*}$ Corresponding author.Email: bguntoro57@gmail.com
}

\begin{abstract}
The function of grounding is to neutralize disturbances that occur in electric voltages such as short circuits and leakage currents in equipment. So the grounding system that already used will be able to drain the disturbance that occurs due to leakage currents or short circuits to the grounding terminal and then delivered again to the conduit or conductor and then delivered again to the grounding pole or electrode, then the electrode will neutralize it to the ground. In regard to this point, the grounding system is expected to minimize damage to equipment due to interference with electrical voltage. The smaller the grounding resistance value, the better the grounding system. The results of the analysis show that the value of grounding resistance will be smaller if the depth of planting, the number of electrodes planted, and the planting distance are increased. The Tomat feeder distribution substation itself still has grounding values that are not in accordance with the PUIL standard, article 3.13.2.10. This is due to the lack of moisture in the soil.
\end{abstract}

Keywords: grounding resistance, tomato feeder, PHB TR

\section{INTRODUCTION}

The distribution substation certainly has a grounding system that functions as protection from various disturbances such as leakage currents and lightning strikes. However, the performance of a grounding system cannot always be said to be good, because basically, the value of the grounding resistance can vary by several factors. Therefore, it is necessary to analyze the grounding system in an electric power system such as distribution substations in a feeder in order to find out whether the grounding resistance value still meets the PUIL standard article 3.13.2.10 or not and according to the General Requirements for Electrical Installation standards (PUIL) article 3.13.2.10 that a good grounding system must have an earthing or grounding resistance with a value of $\leq 5 \Omega$ in order to conduct the fault current properly.

\section{REVIEW OF LITERATURE}

\subsection{Grounding System}

The grounding system is a conductive connection system that connects the system, equipment body and installation to the earth or ground so that it can protect humans from electric shock, and secure installation components from the dangers of abnormal voltages or currents.

\subsection{Types of Grounding System}

There are various types of grounding systems and each of them has advantages and disadvantages. However, the following discussion is not intended to discuss the advantages and disadvantages of this method, but rather focuses on the types of neutral point grounding that are commonly used. The type of grounding of the system will determine its protection scheme, therefore, it is very important to know this type of grounding.

There are five types of grounding systems, namely:

1. TN-C (Terre Neutral-Combined): Ground and Neutral channel are combined.

2.TN-C-S (Terre Neutral-Combined-Separated): Ground and Neutral channel are joined and separated.

3. TN-S (Terre Neutral-Separated): Ground and Neutral channel are separated.

4. TT (Terre Terre): Ground and Ground channel.

5. IT (Impedance Terra) System: Ground channel through impedance. 


\subsection{Grounding Resistance}

As stated earlier, the grounding resistance can be obtained as small as possible. However, practically it is not always easy to get it because many factors affect the grounding resistance.

The factors that affect the value of grounding resistance are:

1. The electrode shape. There are various forms of electrodes that are widely used, such as types of rods, ribbons and plates.

2. Type of material and size of the electrode. As a consequence of their placement in the ground, the electrodes are selected from certain materials that have excellent conductivity and are resistant to the damaging properties of the soil, such as corrosion. The electrode size is chosen which has the most effective contact with the ground.

3. Number / configuration of electrodes. To obtain the desired grounding resistance and if there is not enough electrode with one electrode, more electrodes can be used with a variety of mounting configurations in the ground.

4. Depth of planting / planting in the ground. This planting depends on the type and properties of the soil. Some are more effective when planted deep, but some are planted in a shallow manner.

5. Natural factors. Soil type: loose, sandy, rocky soil, etc.; soil moisture: the higher the humidity or water content in the soil, the lower the soil resistivity; soil mineral content: higher salt content lowers soil resistivity and increases corrosion; soil temperature: the temperature will have an effect when it reaches freezing temperatures and below. For a tropical region like Indonesia there is no problem with temperature because the soil temperature is above the freezing point value.

\subsection{Soil Resistivity}

The soil type resistance determines the grounding resistance of the grounding electrodes. Soil type resistance is given in Ohm-meters, which represents the soil resistance measured from the ground that is 1 meter-sided cuboid.

What determines the resistivity of this soil does not only depend on the type of soil, but is influenced by moisture, mineral content and temperature (temperature has no effect when it is above the freezing point of water). Therefore, soil type resistance can vary from one place to another depending on the properties it has. As a rough guideline, table 2.2 contains soil type resistances in Indonesia.
Table 1. Soil Resistivity

\begin{tabular}{|c|c|c|c|c|c|c|}
\hline 1 & 2 & 3 & 4 & 5 & 6 & 7 \\
\hline Soil Type & Swampland & $\begin{array}{c}\text { Clay } \\
\text { and } \\
\text { field } \\
\text { soil }\end{array}$ & $\begin{array}{c}\text { Wet } \\
\text { Sand }\end{array}$ & $\begin{array}{c}\text { Wet } \\
\text { Gravel }\end{array}$ & $\begin{array}{c}\text { Dry } \\
\text { sand } \\
\text { and } \\
\text { gravel }\end{array}$ & $\begin{array}{c}\text { Rocky } \\
\text { ground }\end{array}$ \\
\hline $\begin{array}{c}\text { Resistance } \\
\text { type } \\
\text { (ohm-m) }\end{array}$ & 300 & 100 & 200 & 500 & 1000 & 3000 \\
\hline
\end{tabular}

This knowledge is particularly important for grounding system designers. Before carrying out other actions, the first thing to know is the characteristics of the soil where the grounding electrode will be installed to determine the resistivity of the earth. If necessary, measure soil resistance.

However, it should be noted that the characteristics of the soil may vary from one season to another. This should really be considered in the design of the grounding system. If something like this happens, then what can be used as a benchmark is the condition when the earth type resistance is highest. This is in anticipation so that grounding prisoners remain eligible for the season when the type of grounding resistance is highest, for example during the dry season.

\subsection{Grounding System at Portal Substation}

The parts that are grounded in the portal substation are:

- Transformer secondary neutral terminal

- $\quad$ Lightning Arrester (LA)

- Open conductive parts, such as low-voltage switchboard and transformer bodies.

The Lightning Arrester earthing electrode is separated from the transformer neutral point earthing electrode. To avoid damage or theft, the grounding conductor must be protected by galvanized pipe $3 / 4 \mathrm{inch}$, 3 meters high above the ground.

The grounding conductor uses copper wire (BC) measuring $50 \mathrm{~mm} 2$ and the grounding electrode uses a rod electrode at least 3 meters long with a minimum of $20 \mathrm{~cm}$ planted into the ground. 


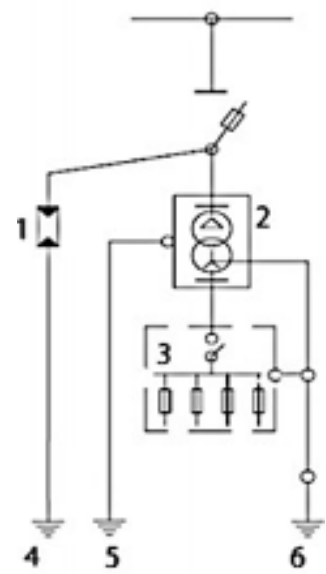

Figure 1. SLD of Portal Substation Grounding System

Picture information:

1. LA (Lightning Arrester)

2. Transformer

3 PHB - TR (LV Switchboard)

4. LA Grounding System

5. Body Transformer Grounding System

6. Transformer \& LV Switchboard Secondary Neutral Grounding System.

\subsection{Counting the Grounding Resistance}

The usual approximation formula for rod electrodes was developed by Prof. H.B Dwight from The Massachusetts Institute of Technology as follows:

1. One electrode rod:

1. One electrode rod:

$$
\mathrm{R}=\frac{\rho}{2 \pi L}\left(\ln \frac{4 L}{a}-1\right)
$$

2. Two electrode rod:

$$
\mathrm{R}=\frac{\rho}{2 \pi L}\left(\operatorname{In} \frac{4 L}{a}-1\right)+\frac{\rho}{4 \pi L}\left(1-\frac{L^{2}}{3 S^{2}}+\frac{2}{5} \frac{L^{4}}{S^{4}}\right)(2)
$$

Where :

$\mathrm{P} \quad=$ Resistivity $(\mathrm{ohm}-\mathrm{cm})$

$\mathrm{S} \quad=$ Distance between electrodes $(\mathrm{cm})$

L = Depth of electrode erection (from ground level to electrode tip) $(\mathrm{cm})$

a $=$ the radius of the cross section of the electrode or ground peg $(\mathrm{cm})$

$\mathrm{R}=$ Resistance of the electrode or peg to the ground (ohms)

\subsection{Research Procedure Flowchart}

All stages of the research are described in the form of a flow chart as in Figure 2:

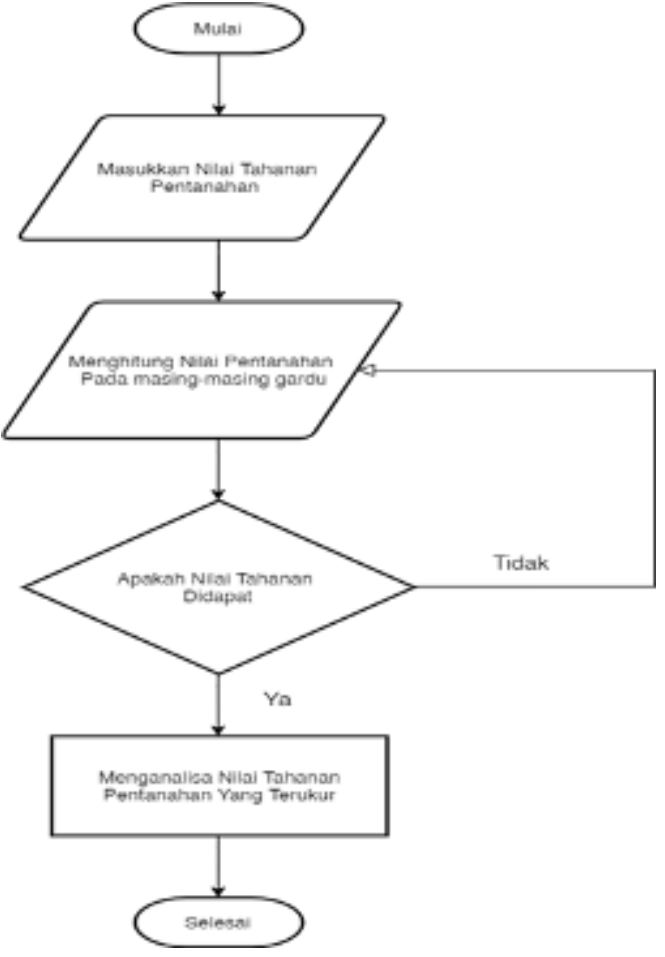

Figure 2. Calculation of Grounding Resistance Flowchart

\subsection{Equipment}

This research begins by collecting data and detailing the main issues related to the discussion. To simplify the measurement process, equipment is needed in this study. The equipment used in data collection is as follows:

\subsubsection{Digital Earth Tester}

The grounding resistance measuring instrument used at ULP Mariana is the Digital Earth Tester SEW 1120ER, where this measuring instrument has 3 terminals, namely a green terminal (terminal $\mathrm{E})$, a yellow terminal ( $\mathrm{P}$ terminal), a red terminal $(\mathrm{C}$ terminal). Where these three terminals function as the input terminal of the measuring instrument. This measuring instrument also consists of 2 buttons, namely: the Test Button which functions as a button to test the ground resistance, and a Hold Button which functions to set the value of grounding resistance. The specifications of the SEW 1120ER Digital Earth Tester are:

1. Measuring Ranges:

Earth Resistance: 0-20 ohm/ 0-200 ohm/ 0-

2000 ohm. Earth Voltage: 0-200 V AC (40-500 $\mathrm{Hz})$

2. Power Source: 1,5 SUM-3 (AA) x 8

3. Weight: 600 gram (battery included)

4. Accessories: 
Test leads (red $20 \mathrm{~m}$, yellow 10m, green $5 \mathrm{~m}$ ). Auxiliary earth spikes. Simplified measurement probe. Shoulder belt, Instruction manual, Batteries.

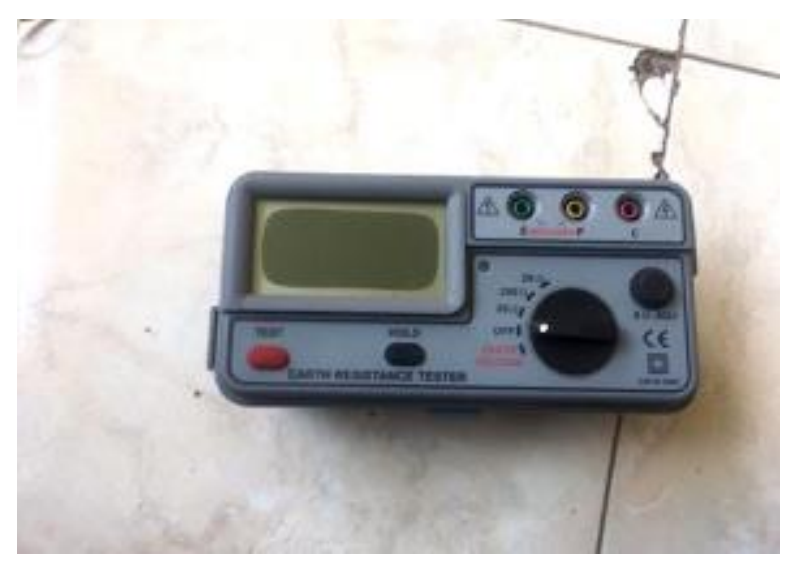

Figure 3. Digital Earth Tester

\subsubsection{Auxiliary Electrodes}

The auxiliary electrode functions as an input aid for terminals $\mathrm{C}$ and $\mathrm{F}$, where terminal $\mathrm{C}$ is for current and terminal $\mathrm{F}$ is for voltage. The auxiliary electrodes used in measurements at distribution substations in Tomat feeders are 2 stems.

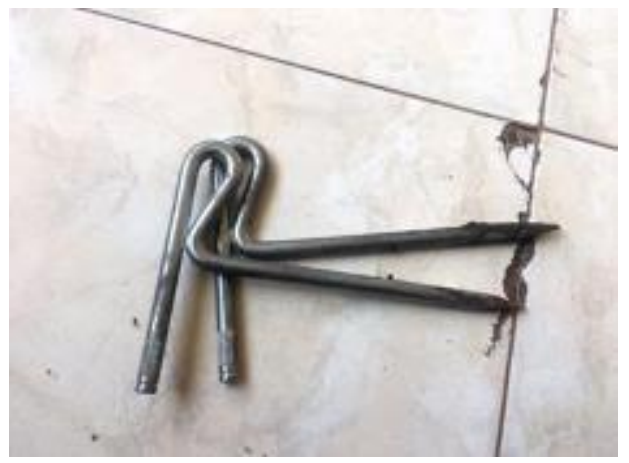

Figure 4. Auxiliary Electrode

\subsubsection{Green Cable}

The green cable is used to connect the main electrode (the electrode to be measured) with a digital earth tester via terminal $E$. The specification of this cable is NYAF $2.5 \mathrm{~mm} 2$ with a length of 5 meters.

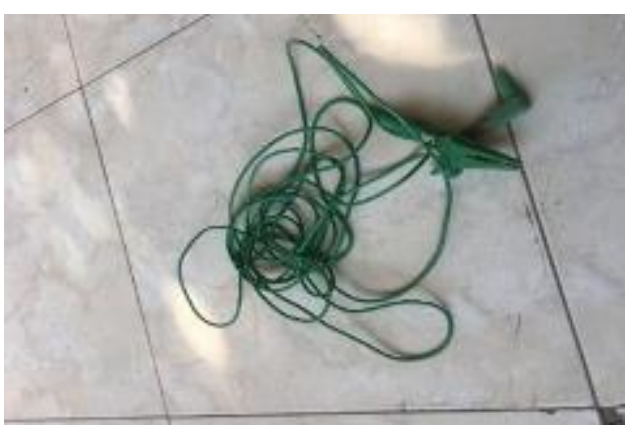

Figure 5. Green Cable

2.8.4. Yellow Cable
The yellow cable is used to connect the first auxiliary electrode to the measuring instrument through the terminal F. The first auxiliary electrode is installed 5-10 meters from the main electrode. This cable specification is NYAF $2.5 \mathrm{~mm} 2$ with a length of 10 meters.

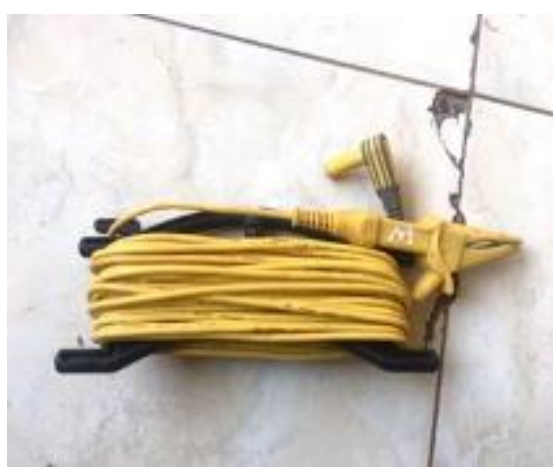

Figure 6. Yellow Cable

\subsubsection{Red Cable}

The red cable is used to connect the second auxiliary electrode to the measuring instrument via terminal $\mathrm{C}$. The second auxiliary electrode is installed 15-20 meters from the main electrode. This cable specification is NYAF $2.5 \mathrm{~mm} 2$ with a length of 20 meters.

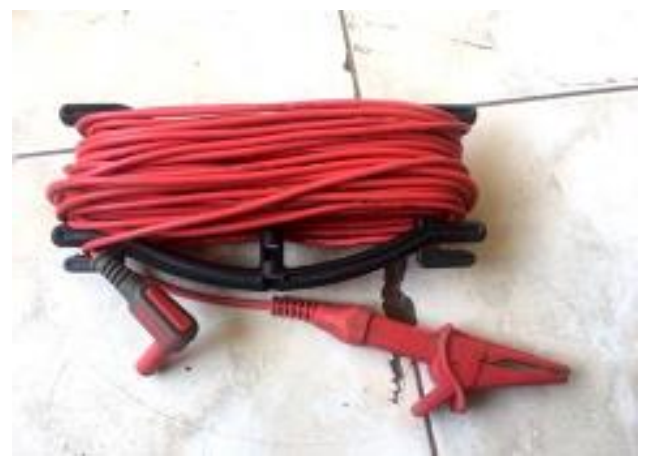

Figure 7. Red Cable

2.8.6. Location Diagram of the Tomat Feeder Distribution Substation for Cinta Manis Service

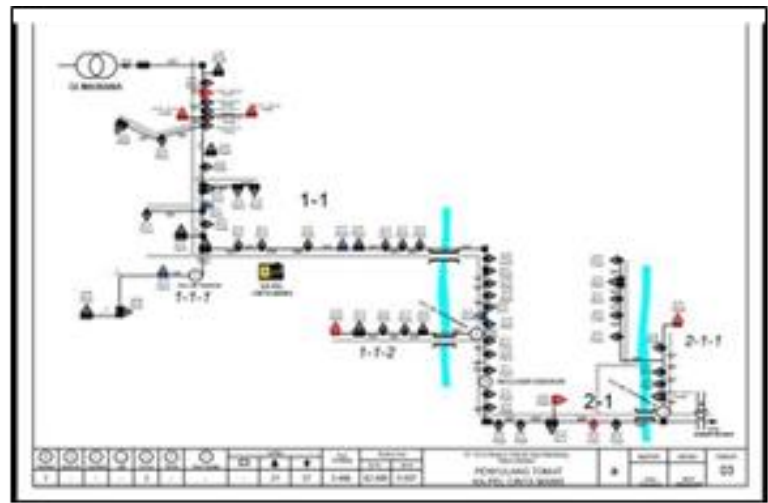

Figure 8. Location Diagram of the Tomat Feeder Distribution Substation for Cinta Manis Service 


\subsubsection{Grounding System at Tomat Feeder Distribution Substation at ULP Mariana}

Every earthing of portal substations at the Tomat feeder of PT. PLN (Persero) ULP Mariana uses a single electrode (1 rod) and based on how it is installed it can be said that the earthing / grounding uses a Rod system where the earthing electrode is implanted vertically or perpendicular to the ground.

Based on the survey results in the field, the grounding system at each distribution substation is divided into three, namely:

- The grounding system in the transformer body

- $\quad$ Grounding system in lightning arresters

- Earthing system at the neutral point and on the body panel for low voltage.

Each grounding system at each distribution substation has the same data specifications, the data for the grounding components are:

- Electrode shape: Rod electrode

- $\quad$ Electrode material: Copper coated steel

- $\quad$ Electrode length: 2.5 meters

- $\quad$ Electrode Cross-sectional Diameter: $15 \mathrm{~mm}$

- Type of Conductor: AAAC

- Number of electrodes per substation: 3 rods o 1 rod for the transformer body

o 1 rod for lightning arrester

o 1 bar for neutral point and body panel for low voltage connection.

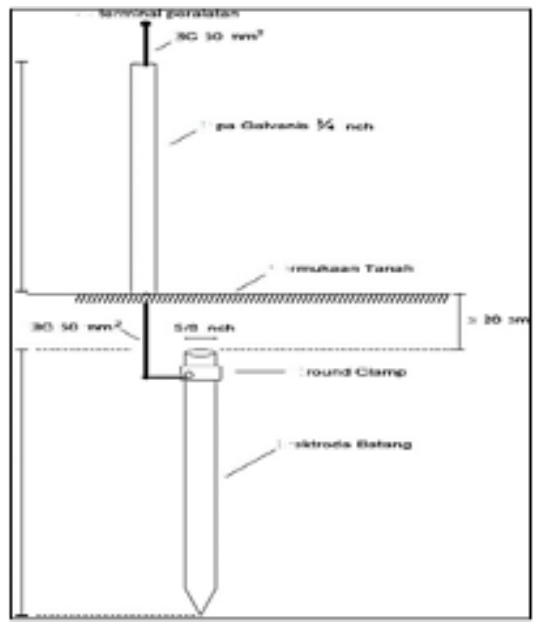

Figure 9. Grounding System of Tomat Feeder Portal Substation

\section{MEASUREMENT DATA}

This measurement data is obtained from third parties who install grounding systems at distribution substations in Tomat feeders, measurement data can be seen in table 2 below:

Table 2. Grounding data for Tomat Feeder distribution substations at PT PLN (Persero) ULP Mariana

\begin{tabular}{|c|c|c|c|c|}
\hline \multirow[b]{2}{*}{$\begin{array}{l}\text { substati } \\
\text { on } \\
\text { name }\end{array}$} & \multirow[b]{2}{*}{ Soil type } & \multicolumn{3}{|c|}{$\begin{array}{l}\text { Earthing } \\
\text { soil (Ohm) }\end{array}$} \\
\hline & & $\begin{array}{l}\mathrm{L} \\
\mathrm{A}\end{array}$ & $\begin{array}{l}\text { Neutral } \\
\text { Transforma } \\
\text { tor and } \\
\text { PHB TR }\end{array}$ & $\begin{array}{l}\text { Transforma } \\
\text { tor body }\end{array}$ \\
\hline $\begin{array}{l}\mathrm{PH} \\
0489\end{array}$ & $\begin{array}{l}\text { swampla } \\
\text { nd }\end{array}$ & $\begin{array}{l}1.1 \\
7\end{array}$ & 1.07 & 1.01 \\
\hline $\begin{array}{l}\mathrm{PH} \\
0034\end{array}$ & $\begin{array}{l}\text { swampla } \\
\text { nd }\end{array}$ & $\begin{array}{l}2.0 \\
1\end{array}$ & 2.07 & 2.10 \\
\hline $\begin{array}{l}\mathrm{PH} \\
0474\end{array}$ & $\begin{array}{l}\text { swampla } \\
\text { nd }\end{array}$ & $\begin{array}{l}2.0 \\
1\end{array}$ & 1.08 & 1.04 \\
\hline $\begin{array}{l}\mathrm{PH} \\
0036\end{array}$ & Clay & 3.8 & 3.8 & 3.8 \\
\hline $\begin{array}{l}\mathrm{PH} \\
0035\end{array}$ & $\begin{array}{l}\text { swampla } \\
\text { nd }\end{array}$ & $\begin{array}{l}1.1 \\
3\end{array}$ & 1.23 & 1.08 \\
\hline $\begin{array}{l}\mathrm{PH} \\
0533\end{array}$ & $\begin{array}{l}\text { swampla } \\
\text { nd }\end{array}$ & $\begin{array}{l}2.0 \\
7\end{array}$ & 1.98 & 2.06 \\
\hline $\begin{array}{l}\mathrm{PH} \\
0071\end{array}$ & Clay & 3.9 & 3.9 & 3.8 \\
\hline $\begin{array}{l}\mathrm{PH} \\
0037\end{array}$ & Clay & 4.2 & 3.8 & 3.8 \\
\hline $\begin{array}{l}\mathrm{PH} \\
0521\end{array}$ & Clay & 4.3 & 4.0 & 3.8 \\
\hline $\begin{array}{l}\mathrm{PH} \\
0540\end{array}$ & Clay & $\begin{array}{l}6.1 \\
7\end{array}$ & 6.01 & 6.07 \\
\hline $\begin{array}{l}\mathrm{PH} \\
0447\end{array}$ & Clay & $\begin{array}{l}4.4 \\
3\end{array}$ & 4.4 & 4.38 \\
\hline $\begin{array}{l}\mathrm{PH} \\
0529\end{array}$ & $\begin{array}{l}\text { swampla } \\
\text { nd }\end{array}$ & $\begin{array}{l}1.0 \\
9\end{array}$ & 1.08 & 1.04 \\
\hline $\begin{array}{l}\mathrm{PH} \\
0044\end{array}$ & Clay & $\begin{array}{l}4.3 \\
5\end{array}$ & 4.41 & 4.45 \\
\hline $\begin{array}{l}\text { PHX } \\
076\end{array}$ & $\begin{array}{l}\text { swampla } \\
\text { nd }\end{array}$ & $\begin{array}{l}2.4 \\
4\end{array}$ & 2.38 & 2.35 \\
\hline $\begin{array}{l}\mathrm{PH} \\
0476\end{array}$ & $\begin{array}{l}\text { swampla } \\
\text { nd }\end{array}$ & $\begin{array}{l}1.0 \\
9\end{array}$ & 1.08 & 1.04 \\
\hline $\begin{array}{l}\mathrm{PH} \\
0446\end{array}$ & $\begin{array}{l}\text { swampla } \\
\text { nd }\end{array}$ & $\begin{array}{l}1.9 \\
8\end{array}$ & 1.95 & 2.01 \\
\hline $\begin{array}{l}\mathrm{PH} \\
0444\end{array}$ & $\begin{array}{l}\text { swampla } \\
\text { nd }\end{array}$ & $\begin{array}{l}1.0 \\
1\end{array}$ & 1.23 & 1.08 \\
\hline $\begin{array}{l}\mathrm{PH} \\
0540\end{array}$ & Clay & 4.4 & 4.35 & 4.45 \\
\hline $\begin{array}{l}\mathrm{PH} \\
0043\end{array}$ & Clay & 4.2 & 4.7 & 4.4 \\
\hline $\begin{array}{l}\mathrm{PH} \\
0533\end{array}$ & Clay & 4.0 & 3.8 & 4.42 \\
\hline
\end{tabular}




\section{RESULTS AND DISCUSSION}

\subsection{Measurement Results}

In obtaining the earthing or grounding system resistance value of each distribution substation with a portal type in the Tomat Feeder, measurements are taken directly using a digital Earth Tester. Based on these measurements, the following earthing resistance values are obtained:

Table 3. Measurement Data on Tomat Feeder

\begin{tabular}{|c|c|c|c|c|}
\hline \multirow[b]{2}{*}{$\begin{array}{l}\text { substat } \\
\text { ion } \\
\text { name }\end{array}$} & \multirow[b]{2}{*}{$\begin{array}{l}\text { Soil } \\
\text { type }\end{array}$} & \multicolumn{3}{|r|}{$\begin{array}{l}\text { value of } \\
\text { land } \\
\text { detention }\end{array}$} \\
\hline & & $\begin{array}{l}\text { Neutral } \\
\text { Transform } \\
\text { ator and } \\
\text { PHB body }\end{array}$ & $\begin{array}{l}\text { Lightn } \\
\text { ing } \\
\text { Arrest } \\
\text { er }\end{array}$ & $\begin{array}{l}\text { Transform } \\
\text { ator body }\end{array}$ \\
\hline $\begin{array}{l}\mathrm{PH} \\
0489 \\
\end{array}$ & $\begin{array}{l}\text { swampl } \\
\text { and }\end{array}$ & 2.88 & 3.83 & 2.2 \\
\hline $\begin{array}{l}\mathrm{PH} \\
0034\end{array}$ & $\begin{array}{l}\text { swampl } \\
\text { and }\end{array}$ & 0.68 & 0.83 & 0.48 \\
\hline $\begin{array}{l}\mathrm{PH} \\
0474\end{array}$ & $\begin{array}{l}\text { swampl } \\
\text { and }\end{array}$ & 1.27 & 1.66 & 1.55 \\
\hline $\begin{array}{l}\mathrm{PH} \\
0035 \\
\end{array}$ & $\begin{array}{l}\text { swampl } \\
\text { and }\end{array}$ & 1.42 & 1.75 & 1.71 \\
\hline $\begin{array}{l}\mathrm{PH} \\
0533 \\
\end{array}$ & $\begin{array}{l}\text { swampl } \\
\text { and }\end{array}$ & 0.12 & 1.97 & 0.11 \\
\hline $\begin{array}{l}\mathrm{PH} \\
0529\end{array}$ & $\begin{array}{l}\text { swampl } \\
\text { and }\end{array}$ & 1.48 & 1.54 & 1.99 \\
\hline $\begin{array}{l}\mathrm{PH} \\
0476\end{array}$ & $\begin{array}{l}\text { swampl } \\
\text { and }\end{array}$ & 2.76 & 2.59 & 2.29 \\
\hline $\begin{array}{l}\mathrm{PH} \\
0446 \\
\end{array}$ & $\begin{array}{l}\text { swampl } \\
\text { and }\end{array}$ & 0.33 & 0.69 & 0.76 \\
\hline $\begin{array}{l}\text { PHX } \\
0017\end{array}$ & $\begin{array}{l}\text { swampl } \\
\text { and }\end{array}$ & 2.01 & 2.58 & 2.15 \\
\hline $\begin{array}{l}\mathrm{PH} \\
0444\end{array}$ & $\begin{array}{l}\text { swampl } \\
\text { and }\end{array}$ & 3.18 & 3.15 & 2.95 \\
\hline $\begin{array}{l}\mathrm{PH} \\
0036 \\
\end{array}$ & Clay & 3.41 & 3.45 & 3.39 \\
\hline $\begin{array}{l}\mathrm{PH} \\
0071\end{array}$ & Clay & 3.95 & 4.02 & 3.9 \\
\hline $\begin{array}{l}\mathrm{PH} \\
0037\end{array}$ & Clay & 4.49 & 4.87 & 4.49 \\
\hline $\begin{array}{l}\mathrm{PH} \\
0521\end{array}$ & Clay & 5.69 & 5.52 & 2.75 \\
\hline $\begin{array}{l}\mathrm{PH} \\
0540\end{array}$ & Clay & 4.97 & 5 & 5.04 \\
\hline $\begin{array}{l}\mathrm{PH} \\
0477\end{array}$ & Clay & 9.05 & 6.83 & 7.11 \\
\hline $\begin{array}{l}\mathrm{PH} \\
0044\end{array}$ & Clay & 10.65 & 11.07 & 10.67 \\
\hline $\begin{array}{l}\mathrm{PH} \\
0038\end{array}$ & Clay & 20.2 & 20.1 & - \\
\hline $\begin{array}{l}\mathrm{PH} \\
0369 \\
\end{array}$ & Clay & 21.8 & 21.6 & 20.9 \\
\hline
\end{tabular}

The graph of the measurement results can be seen in the following figure:

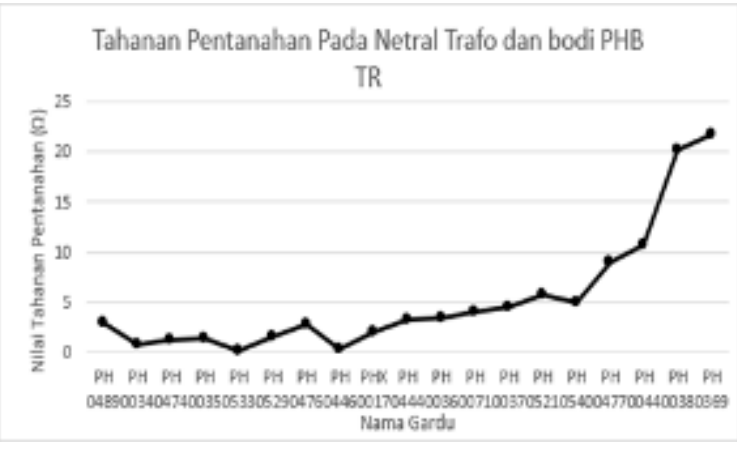

Figure 10. Graphic Earth Resistance Value at Neutral Transformer and PHB TR body

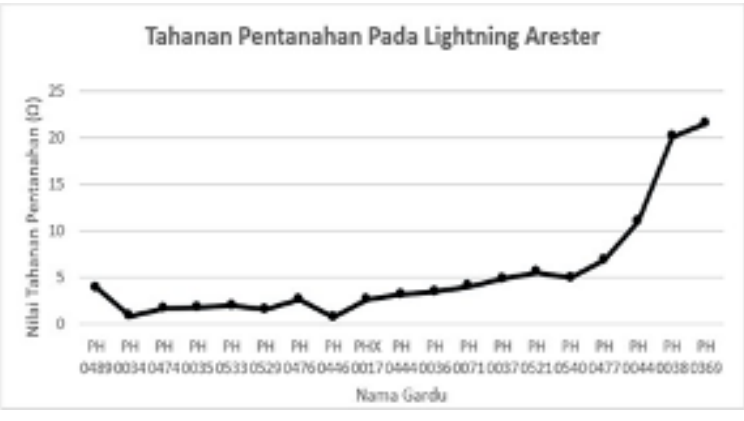

Figure 11. Graph of Earth Resistance Value on Lightning Arrester

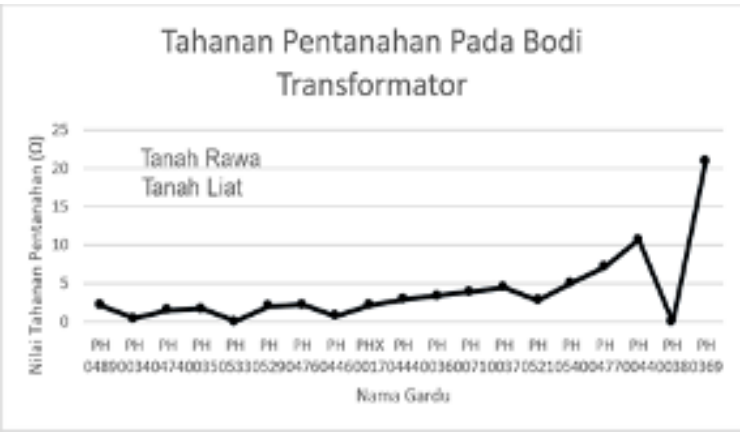

Figure 12. Graph of the Earth Resistance Value on the Transformer Body

\subsection{The Calculation Results}

conducting interviews with employees and Yantek at PT. PLN (Persero), the existing grounding system at distribution substations in Tomat feeders uses one electrode rod for each of the grounding systems (lightening arrester, transformer neutral and PHB TR body, and transformer body) so formula 2.1 is used for calculations. The substation measured has 2 specifications on different types of soil, namely swampland and clay.

1. At substations $\mathrm{PH} 0489, \mathrm{PH}$ 0034, $\mathrm{PH} 0474, \mathrm{PH}$ 0035, PH 0533, PH 0529, PH 0476, PH 0446, PHX 0017, and PH 0444, have a type of swampy soil, so the calculation results are obtained: 


$$
\begin{aligned}
\mathrm{R} & =\frac{\rho}{z \pi L}\left(\ln \frac{4 L}{a}-1\right) \\
& =\frac{30}{2 \times 3,14 \times 2,5}\left(\ln \frac{4 x 2,5}{0,015}-1\right) \\
& =\frac{30}{15,7}\left(\ln \frac{10}{0,015}-1\right) \\
& =1,91(\ln 666,657-1) \\
& =1,91(6,5-1) \\
& =1,91(5,5) \\
& =10,5 \Omega
\end{aligned}
$$

2. At distribution substations $\mathrm{PH} 0036, \mathrm{PH} 0071, \mathrm{PH}$ 0037, PH 0521, PH 0540, PH 0477, PH 0038, and PH 0369 , have the type of clay, so the calculation results are

\begin{tabular}{|c|c|c|c|c|c|}
\hline \multirow[b]{2}{*}{$\begin{array}{l}\text { Nama } \\
\text { Gardu }\end{array}$} & \multirow[b]{2}{*}{ Jenis Tamah } & \multicolumn{3}{|c|}{ Nilai Tahanen Pentanaban $(\Omega)$} & \multirow[b]{2}{*}{$\begin{array}{c}\text { Hasil } \\
\text { Perhitungan }\end{array}$} \\
\hline & & $\begin{array}{c}\text { Netral Trafo dan } \\
\text { Bodi PHB }\end{array}$ & $\begin{array}{l}\text { Lightning } \\
\text { Arester }\end{array}$ & $\begin{array}{l}\text { Bodi } \\
\text { Trafe }\end{array}$ & \\
\hline PH 0489 & Tansh Rawa & 2,88 & 3,83 & 2,2 & 10,5 \\
\hline $\mathrm{PH} 00134$ & Tanzh Rawa & 0,68 & 0,83 & 0,48 & 10.5 \\
\hline PH 0474 & Tanah Rawa & 1,27 & 1,66 & 1,55 & 10,5 \\
\hline PH 0035 & Tansh Rawa & 1,42 & 1,75 & 1,71 & 10,5 \\
\hline PH 0533 & Tansh Rawa & 0,12 & 1,97 & 0,11 & 10,5 \\
\hline PH 0529 & Tansh Rawa & 1,48 & 1,54 & 1,99 & 10,5 \\
\hline
\end{tabular}
obtained:

$$
\begin{aligned}
& R=\frac{\rho}{z \pi L}\left(\ln \frac{4 L}{a}-1\right) \\
& =\frac{100}{2 \times 3,14 \times 2,5}\left(\ln \frac{4 \times 2,5}{0,015}-1\right) \\
& =\frac{100}{15,7}\left(\ln \frac{10}{0,015}-1\right) \\
& =6,37(\operatorname{In} 666,667-1) \\
& =6,37(6,5-1) \\
& =6,37(5,5) \\
& =35,04 \Omega
\end{aligned}
$$

\subsection{Comparison of Measurement Results with Calculation Results}

Table 4. Data on Measurement Results and Calculation of Grounding Resistance

Measurement results with calculation results can be displayed in the following graph:

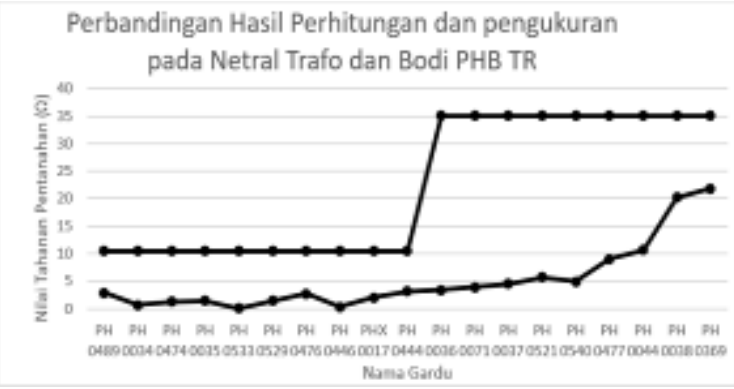

Figure 13. Comparison of Calculation and Measurement Results on Neutral Transformers and PHB TR Bodies

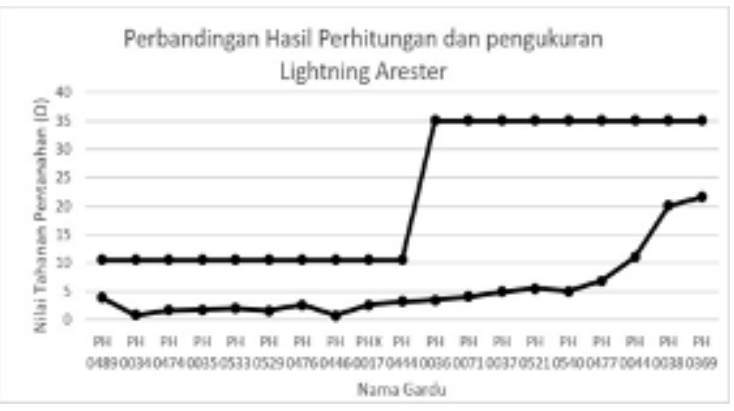

Figure 14. Comparison of the calculation results and measurements of the Lightning Arrester

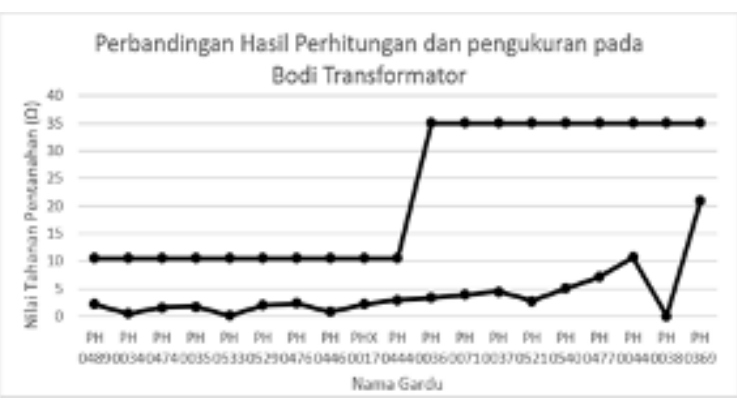

Figure 15. Comparison of Calculation and Measurement Results on the Body Transformer

\subsection{Comparison of Measurement Results Data with Calculation Results}

The comparisons will be displayed using the following graph:

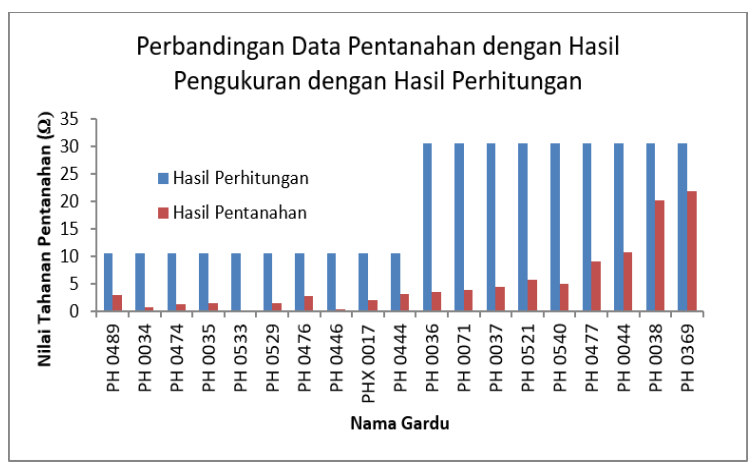


Figure 16. Comparison between Grounding Data and Measurement Results with Calculation Results on Neutral Transformers and PHB TR Bodies

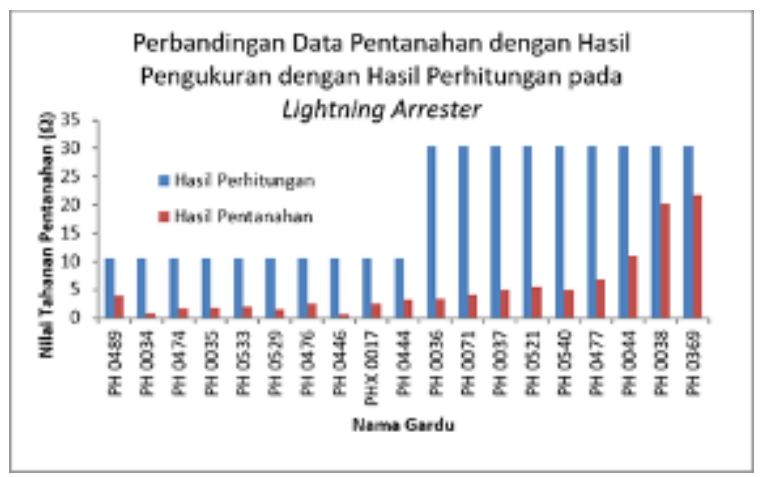

Figure 17. Comparison of Grounding Data with Measurement Results and Calculation Results in Lightning Arrester

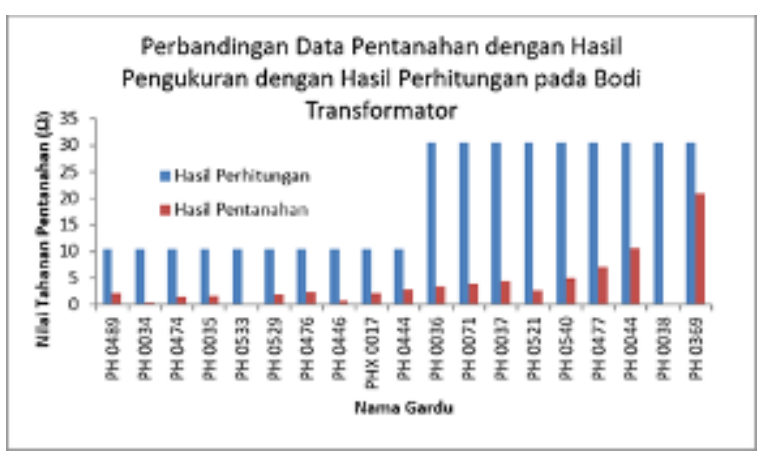

Figure 18. Comparison of Ground Data with Measurement Results and Calculation Results on the Transformer Body

\subsection{Analysis}

From the results of direct measurements in the field using the Digital Earth Tester, it can be explained that the results of measurements of grounding resistance that have been carried out have different resistances.

At the PH 0489 distribution substation located in swampland, the measured earth resistance values at the neutral point plus the PHB TR body, lightning arrester, and transformer body are $2.88 \Omega, 3.83 \Omega$, and $2.2 \Omega$. Based on the standard value of grounding resistance in PUIL article 3.13.2.10, which is $\leq 5 \Omega$, the result of the resistance measured at the $\mathrm{PH} 0489$ distribution substation has met the standard for the permitted grounding resistance value.

At the PH 0034 distribution substation located in swampland, the measured earth resistance values at the neutral point plus the PHB TR body, lightning arrester, and transformer body are $0.68 \Omega, 0.83 \Omega$, and $0.48 \Omega$. Based on the standard of grounding insulation resistance in PUIL article 3.13.2.10, which is $\leq 5 \Omega$, the results of the resistance measured at the $\mathrm{PH} 0034$ distribution substation have met the standard of permitted grounding resistance values.
At the $\mathrm{PH} 0474$ distribution substation located in swampland, the measured grounding resistance value at the neutral point plus the PHB TR body, lightning arrester, and transformer body are $1.27 \Omega, 1.66 \Omega$, and $1.55 \Omega$. Based on the standard of grounding insulation resistance in PUIL article 3.13.2.10, which is $\leq 5 \Omega$, the results of the resistance measured at the $\mathrm{PH} 0474$ distribution substation have met the standard permitted grounding resistance values.

At the PH 0035 distribution substation located in swampland, the measured grounding resistance value at the neutral point plus the PHB TR body, lightning arrester, and transformer body are $1.42 \Omega, 1.75 \Omega$, and $1.71 \Omega$. Based on the standard of grounding insulation resistance in PUIL article 3.13.2.10, which is $\leq 5 \Omega$, the results of the resistance measured at the $\mathrm{PH} 0035$ distribution substation have met the standard permitted grounding resistance values.

At the PH 0533 distribution substation located in swampland, the measured grounding resistance values at the neutral point plus the PHB TR body, lightning arrester, and transformer body are $0.12 \Omega, 1.97 \Omega$, and $0.11 \Omega$. Based on the standard of grounding insulation resistance in PUIL article 3.13.2.10, which is $\leq 5 \Omega$, the result of the resistance measured at the $\mathrm{PH} 0533$ distribution substation has met the standard for the permitted grounding resistance value.

At the PH 0529 distribution substation which is located in a swampland, the measured earth resistance values at the neutral point plus the PHB TR body, lightning arrester, and transformer body are $1.48 \Omega, 1.54$ $\Omega$, and $1.99 \Omega$. Based on the standard of grounding insulation resistance in PUIL article 3.13.2.10, which is $\leq 5 \Omega$, the results of the resistance measured at the $\mathrm{PH}$ 0529 distribution substation have met the standard of permitted grounding resistance values.

At the PH 0476 distribution substation located in swampland, the measured grounding resistance values at the neutral point plus the PHB TR body, lightning arrester, and transformer body are $2.76 \Omega, 2.59 \Omega$, and $2.29 \Omega$. Based on the standard of grounding insulation resistance in PUIL article 3.13.2.10, which is $\leq 5 \Omega$, the result of the resistance measured at the $\mathrm{PH} 0476$ distribution substation has met the standard for the permitted grounding resistance value.

At the PH 0446 distribution substation located in swampland, the measured earth resistance values at the neutral point plus the PHB TR body, lightning arrester, and transformer body are $0.33 \Omega, 0.69 \Omega$, and $0.76 \Omega$. Based on the standard of grounding insulation resistance in PUIL article 3.13.2.10, which is $\leq 5 \Omega$, the result of the resistance measured at the $\mathrm{PH} 0446$ distribution substation has met the standard for the permitted grounding resistance value. 
At the PHX 0017 distribution substation which is in a swampland, the value of grounding resistance measured at the neutral point plus the PHB TR body, lightning arrester, and transformer body is $2.01 \Omega, 2.58$ $\Omega$, and $2.15 \Omega$. Based on the standard of grounding insulation resistance in PUIL article 3.13.2.10, which is $\leq 5 \Omega$, the results of the resistance measured at the PHX 0017 distribution substation have met the standard for the permitted grounding resistance value.

At the PH 0444 distribution substation located in swampland, the measured grounding resistance value at the neutral point plus the PHB TR body, lightning arrester, and transformer body is $3.18 \Omega, 3.15 \Omega$, and $2.95 \Omega$. Based on the standard of grounding insulation resistance in PUIL article 3.13.2.10, which is $\leq 5 \Omega$, the result of the resistance measured at the $\mathrm{PH} 0444$ distribution substation has met the standard for the permitted grounding resistance value.

At the PH 0036 distribution substation which is located in a swampland, the measured earth resistance values at the neutral point plus the PHB TR body, lightning arrester, and transformer body are $3.41 \Omega, 3.45$ $\Omega$, and $3.39 \Omega$. Based on the standard of grounding insulation resistance in PUIL article 3.13.2.10, which is $\leq 5 \Omega$, the results of the resistance measured at the $\mathrm{PH}$ 0036 distribution substation have met the standard permitted grounding resistance values.

At the PH 0071 distribution substation which is in a swampland, the value of grounding resistance measured at the neutral point plus the PHB TR body, lightning arrester, and transformer body is $3.95 \Omega, 4.02 \Omega$, and 3.9 $\Omega$. Based on the standard of grounding insulation resistance in PUIL article 3.13.2.10, which is $\leq 5 \Omega$, the result of the resistance measured at the $\mathrm{PH} 0071$ distribution substation has met the standard for the permitted grounding resistance value.

At the PH 0037 distribution substation located in a swampland, the measured grounding resistance values at the net point, ral plus the PHB TR body, lightning arrester, and transformer body are $4.49 \Omega, 4.87 \Omega$, and $4.49 \Omega$. Based on the standard of grounding insulation resistance in PUIL article 3.13.2.10, which is $\leq 5 \Omega$, the result of the resistance measured at the $\mathrm{PH} 0037$ distribution substation has met the standard for the permitted grounding resistance value.

At the PH 0521 distribution substation which is in a swampland, the measured earth resistance values at the neutral point plus the PHB TR body, lightning arrester, and transformer body are $5.69 \Omega, 5.52 \Omega$, and $2.75 \Omega$. Based on the standard of grounding insulation resistance in PUIL article 3.13.2.10, which is $\leq 5 \Omega$, the result of the resistance measured at the $\mathrm{PH} 0521$ distribution substation has met the standard of the permitted grounding resistance value.
At the PH 0540 distribution substation located in swampland, the measured grounding resistance value at the neutral point plus the PHB TR body, lightning arrester, and transformer body are $4.97 \Omega, 5 \Omega$, and 5.04 $\Omega$. Based on the standard of grounding insulation resistance in PUIL article 3.13.2.10, which is $\leq 5 \Omega$, the result of the resistance measured at the $\mathrm{PH} 0540$ distribution substation has met the standard of the permitted grounding resistance value.

At the PH 0477 distribution substation located in swampland, the measured grounding resistance value at the neutral point plus the PHB TR body, lightning arrester, and transformer body is $9.05 \Omega, 6.83 \Omega$, and $7.11 \Omega$. Based on the standard of grounding insulation resistance in PUIL article 3.13.2.10, which is $\leq 5 \Omega$, the result of the resistance measured at the $\mathrm{PH} 0477$ distribution substation has passed the standard limit for the permitted grounding resistance value, it is advisable to sprinkle salt, bentonite or charcoal around the earthing electrode, deepen it again fixing the electrode to the ground, as well as installing a grounding system that uses 2 parallel electrode rods.

At the PH 0044 distribution substation located in swampland, the measured earth resistance values at the neutral point plus the PHB TR body, lightning arrester, and transformer body

are $10.65 \Omega, 11.07 \Omega$, and $10.67 \Omega$. Based on the standard of grounding insulation resistance in PUIL article 3.13.2.10, which is $\leq 5 \Omega$, the result of the resistance measured at the $\mathrm{PH} 0044$ distribution substation has passed the standard limit for the permitted grounding resistance value, it is advisable to sprinkle salt, bentonite or charcoal around the earthing electrode, deepen it again fixing the electrode to the ground, as well as installing a grounding system that uses 2 parallel electrode rods.

At the PH 0038 distribution substation located in swampland, the measured earth resistance values at the neutral point plus the PHB TR body, lightning arrester, and transformer body are $20.2 \Omega, 20.1 \Omega$, and - $\Omega$. Based on the standard of grounding insulation resistance in PUIL article 3.13.2.10, which is $\leq 5 \Omega$, the result of the resistance measured at the $\mathrm{PH} 0038$ distribution substation has passed the standard limit for the permitted grounding resistance value, it is advisable to sprinkle salt, bentonite or charcoal around the earthing electrode, deepen it again fixing the electrode to the ground, and installing a grounding system that uses 2 parallel electrode rods. As for the grounding system for the transformer body, the wire is not connected to the electrodes, or has been disconnected, so the earth resistance value cannot be measured.

At the PH 0369 distribution substation located in swampland, the measured earth resistance values at the 
neutral point plus the PHB TR body, lightning arrester, and transformer body are $2.8 \Omega, 21.6 \Omega$, and $20.9 \Omega$. Based on the standard grounding insulation resistance in PUIL article 3.13.2.10, which is $\leq 5 \Omega$, the result of the resistance measured at the $\mathrm{PH} 0369$ distribution substation has exceeded the standard limit of the permitted grounding resistance value, it is advisable to sprinkle salt, bentonite or charcoal around the earthing electrode, deepen it again fixing the electrode to the ground, as well as installing a grounding system that uses 2 parallel electrode rods.

For the type of swamp land, all values of earthing resistance still meet the PUIL standard article 3.13.2.10, namely $\leq 5 \Omega$. As for clay type, some of the earthing resistance values exceed the standard. This could be due to corrosion of the electrodes in the field or because of the lack of moisture in the soil.

Then from the calculation results obtained a value of $10.5 \Omega$ on swampland and $35.04 \Omega$ in clay, the calculation value cannot be a reference because the resistance of different types of soil in each place.

It can be seen in the comparison chart between the grounding data and the measurement results with the calculation results, there is a fairly far range of values between the grounding data and the measurement data, this is due to corrosion of some of the rod electrodes in the distribution substation.

It can also be seen from the calculation results that the value of the earthing resistance for clay types is greater than the value of the earthing resistance for swamps, even though each with the same L. This is due to the greater resistivity of clay. Regarding things

This, again refers to equation 2.1, where soil type resistance is directly proportional to the result of earthing resistance, which means that the greater the soil type resistance, the greater the value of the resulting earthing resistance and the difficulty of obtaining a small earthing resistance value.

There are several ways to reduce earthing resistance, namely by sprinkling salt, bentonite and charcoal around the earthing electrodes, deepening using 2 parallel electrode rods. Meanwhile, to overcome the high earthing value due to corrosion on the electrodes, it is advisable to replace the earthing electrode with a new one.

\section{CONCLUSIONS}

From the results and discussion that has been done, conclusions can be drawn as follows:

- Based on the measurement data, the grounding resistance of the portal substation in the Tomat Feeder varies from $0.11 \Omega$ to $21.8 \Omega$.

- Based on the results of the calculation, the grounding resistance value is $10.5 \Omega$ for swamps and $35.04 \Omega$ for clay.

- From the measurement results, for the type of swamp land, all values of grounding resistance still meet the PUIL standards for article 3.13.2.10, namely $\leq 5 \Omega$. As for clay type soils, some of the grounding resistance values have exceeded the standard.

- The cause of most of the grounding resistance value for clay that has exceeded the standard is corrosion of the electrodes in the field and lack of moisture.

\section{REFERENCES}

[1] Adiarta, Agus. 2017. Dasar-dasar Instalasi. Depok: PT Raja Grafindo Persada

[2] Sayogo, Bartien dkk. 2014. Penjelasan PUIL 2011 (Persyaratan Umum Instalasi Listrik 2011). Jakarta: Kementrian Energi dan Sumber Daya Mineral Direktorat Jendral Ketenaga listrikan

[3] Sumardjati, Prih dkk. 2008. Teknik Pemanfaatan Tenaga Listrik Jilid 1. Jakarta: Direktorat Pembinaan Sekolah Menengah Kejuruan.

[4] Tim PUSDIKLAT. 2010. Buku 4 Standar Konstruksi Gardu Distribusi dan Gardu Hubung Tenaga Listrik. Jakarta: PT. PLN.

[5] Grounding Penangkal Petir. 2019. Grounding System. http://pakarpetir.com/grounding- system2/ (diakses pada tanggal 25 April 2019)

[6] Persyaratan Umum Instalasi Listrik (PUIL) 2000

[7] Pabla, As dan Abdul Hadi. 1991. Sistem Distribusi Daya Listrik. Jakarta : Erlangga 